\title{
Wellbeing for sale: Representations of yoga in commercial media ${ }^{1}$
}

\author{
LIINA PUUSTINEN \\ University of Helsinki \\ MATTI RAUTANIEMI \\ Åbo Akademi University
}

\begin{abstract}
This article focuses on how spirituality and commercialism are intertwined in the representations of yoga in the media. For this study, articles on yoga were collected from seven Finnish popular magazines, and analyzed using qualitative close reading guided by sensitizing concepts of subjective wellbeing spirituality and prosumerism. The results show that looks, wellbeing and health are found to be the main selling points of yoga, whereas spirituality is used as a distinguishing device and a tool for constructing a consumer identity associated with 'spiritual' values. The material also raises questions on the possibility of anti-consumerist trends within contemporary yoga.
\end{abstract}

Keywords: yoga, spirituality, wellbeing, consumer culture, media representations

According to a recent survey there are roughly $100,000-200,000$ practitioners of yoga in Finland (Gallup Ecclesiastica 2011). Another survey gives an estimate of 62,000 active practitioners and 64,000 potential practitioners (Suomen kuntoliikuntaliitto 2010). In 2008, the national broadcasting corporation YLE ran a headline on their website: 'Finns are yoga enthusiasts' commenting on the high interest in yoga in proportion to the country's population of five million. Yoga's current global popularity is evidenced, and likely also produced, by the fact that it is often featured in various types of

1 We thank the editors in chief of Cosmopolitan, ET, Hyvä Terveys, Kodin Kuvalehti, Me Naiset, Sara and Sport magazines for giving a permission to use the data, and Jenna Parmala for data collection. Special thanks to Suzanne Newcombe and Don Slater for their comments to the manuscript.

2 YLE online news (23.10.2008). 'Suomalaiset ovat kovia joogaamaan'. http://yle.fi/uutiset/ suomalaiset_ovat_kovia_joogaamaan/6116323 http://olotila.yle.fi/mina/hyvinvointi/ suomalaiset-ovat-kovia-joogaamaan. 
media, especially magazines. The current popularity of yoga is often linked with the rise of non-institutional religiosity, popularly referred to as 'spirituality'. The aim of this article is to study how spirituality and commercialism are intertwined in the representations of yoga in the Finnish print media.

Most popular forms of yoga in Finland fall into the category of modern postural yoga (henceforth MPY), referring to forms of yoga which focus on physical postures (asanas) and breathing exercises (pranayama) (De Michelis 2004). ${ }^{3}$ Many MPY practitioners also ascribe some degree of spiritual significance to the practise (Hasselle-Newcombe 2005; Langøien 2012; Nevrin 2008). Most forms of MPY can thus be located within the context of noninstitutional and subjective religiosity that has gained popularity since the mid-twentieth century (Heelas \& Woodhead 2005, Heelas 2008, Taira 2009).

Several authors have convincingly argued that the proliferation of noninstitutional religiosity is connected with spread of capitalism, neoliberal policies and the rise of consumer culture (Lau 2000, Possamai 2003; Carrette \& King 2005; Rindfleish 2006; Taira 2006; Dawson 2013; Gauthier, Martikainen \& Woodhead 2013a). While the relationship between different types non-institutional religiosity and consumerism is well-documented (e.g. Rindfleish 2006, Possamai 2003, Carrette \& King 2005, Lau 2000, Taira 2009), only a handful of studies have focused specifically on the relationship between MPY and consumerism. These have concerned, for instance, copyright issues in transnational commercial yoga (Fish 2006), the re-appropriation of yoga among Indian consumers (Askergaard \& Eckhardt 2012), branding of popular schools of yoga in America (Jain 2012), and the connection between environmentalism, capitalism and yoga among the transnational cosmopolitan middle class (Strauss \& Mandelbaum 2013).

Our study participates in this emerging discussion on MPY and consumerism by looking at empirical representations of yoga in seven Finnish popular magazines (Cosmopolitan, ET, Hyvä Terveys, Kodin Kuvalehti, Me Naiset, Sara and Sport), mainly aimed at female audiences, or, in the case of $E T$, at senior citizens. Modern postural yoga is known in particular as a female activity (Newcombe 2007). Also, in general in the consumer society, where women are seen as the principal consumers, femininity has a cultural connection to consumption (Fisher \& Bristor 1993; Bowlby 2002). We focus

3 Yoga styles, which emphasize (sitting) meditation, are usually referred to in the media simply as 'meditation'. While meditation is central to most pre-modern yoga styles, nowadays it is customary to speak of 'yoga and meditation' as distinct practises even among the practitioners themselves. Bhakti Yoga, a form of ritual worship, is rather marginal in Finland, and is seldom discussed in the mainstream media. 
especially on how 'spirituality' is defined in the representations of yoga, how it is used as a marketing device and how the themes of spirituality and commercialism are intertwined.

\section{Modern postural yoga as spiritual prosumption}

MPY is largely a product of late 19th and early 20th century, differing from earlier interpretations of yoga with regard to its methods and aims of practise. It is heavily influenced by modern ideas of health and wellbeing, as well as an interplay of Indian and Western gymnastics, medicine and psychology (De Michelis 2004; Alter 2004; Singleton 2010; Jain 2014; Strauss 2005). Its recent popularity is intimately connected with the rise of non-institutional spiritualities (Heelas \& Woodhead 2005; Heelas 2008; Davie 1994) and the 'therapeutic ethos' (Lears 1983; Wightman Fox \& Lears 1983), which emphasizes this-worldly self-actualization and the importance of individual psycho-physical health.

The connecting factor between different types of non-institutional spiritualities and associated wellbeing practises, such as MPY, is the emphasis on subjectivity (Heelas 2008). Taira (2006) emphasizes the importance of 'affect' and 'interest' rather than creed and commitment, as important characteristics of what he calls 'liquid religiosity', with reference to Bauman's concept of 'liquid modernity' (Taira 2006; see also Bauman 2000; Speck 2013). This type of religiosity is also often exemplified by the rhetoric of being 'spiritual, but not religious', or what Grace Davie has called 'believing without belonging' (Davie 1994).

Tuomas Martikainen, François Gauthier and Linda Woodhead (2013b) have recently argued that the spread of subjective spiritualities is intimately connected with the implementation of neoliberal economic policies in Western societies, and to the spread of consumerism as a cultural ethos. Neoliberalism is defined as an economic and cultural ideology which involves reducing the role of state and securing the unimpeded function of the market economy (e.g. Harvey 2007; Braedley \& Luxton 2010; Read 2009; Springer 2012).

In neoliberal societies, social life is increasingly mediated by acts of consumption of a range of different products and services. The mechanics of consumer culture have also affected religiosity, as is evident, for example, in the proliferation of subjectivism discussed above, as well as in the increasing commodification of religious and spiritual practises. Like commercial brands, religious affiliations have become ways of constructing and 
expressing selfhood and of forming social networks (Gauthier, Woodhead \& Martikainen 2013b; Rindfleish 2006).

In the case of MPY, commodification is particularly evident in the emergence of innumerable different yoga brands or styles, which are constituted by the selective appropriation of some but not all of the features found across the yoga features found across the yoga market, as well as the development of bodily practises that are marketed as tools for health, wellbeing and personal transformation (Strauss \& Mandelbaum 2013; Jain 2012; De Michelis 2008). In addition to well-known styles derived from acclaimed teachers, such as Iyengar Yoga, Ashtanga Yoga, and Sivananda Yoga, there has been a surge of novel fusion styles such as yoga rave, yogabeats, Dru yoga dance, yoga ballet, iiyoga, yogawalking, Hi-Ki yoga, Chi yoga, hormonal yoga, and so on (Brown \& Aspasia 2010).

In addition to the seemingly boundless variety of paid yoga classes, yoga accessories are a multi-million dollar business, which has led yoga to become an effective brand in its own right (Fish 2006; Philp 2009). Unsurprisingly, yoga has recently also been used to brand make-up, perfumes, tea and even detergents. Certain visual motifs related to yoga, such as the lotus position, have become strong and recognizable symbols in themselves, and are sometimes used in advertising to sell products not in any way connected to yoga, such as beer.

While some authors see MPY as inextricably tied to consumer culture (see Jain 2014; Fish 2006; Strauss \& Mandelbaum 2013), others have seen the commercialization and commodification of yoga as the corruption of an 'authentic' spiritual practise (e.g. Carrette \& King 2005; Lau 2000). The hybridized and 'westernized' forms of MPY are also seen as Foucauldian technologies of the self, which support the neoliberal system (Askergaard \& Eckhardt 2012; Strauss \& Mandelbaum 2013). Certain Hindu groups have voiced their opposition against the popularization and associated commodification of yoga, arguing that yoga is an integral part of Hindu religiosity, and should not be separated from that context (see Jain 2014).

Within the MPY community, criticism has been directed, for example, against Bikram Choudhury, the founder of the extremely popular Bikram Yoga, who has sought to patent a series of 24 postures and is known for having taken legal action against many small yoga entrepreneurs who have taught his sequence of yoga postures without the required license (Fish 2006; Philp 2009; Jain 2014). ${ }^{4}$ Many practitioners have argued that yoga and

4 According to a court order given in December 2012 it seems that Choudhury is losing his right to the trademark. However, the case is still not settled. (Bloomberg 2012). 
money cannot and should not be mixed, as this is seen as jeopardizing the 'spiritual' nature of yoga.

Instead of accepting this black and white dichotomy, where MPY practitioners are seen as either passive consumers or active proponents of anticapitalist spirituality, an alternative way can be sought. ${ }^{5}$ One tool for this is the concept of prosumption, which conflates the notions of production and consumption into one single action (Ritzer \& Jurgenson 2010; Ritzer et al 2012; Zwick et al 2008). Andrew Dawson (2013) has recently applied the concept of prosumption to subjective spirituality, differentiating five aspects of 'spiritual prosumption': agency, site, benefit, repertoire and modality (Dawson 2013).

Agency refers to the idea of the individual subject as both the actor and final authority in matters of spirituality. As many forms of subjective wellbeing spirituality include bodily practises, the site of spiritual prosumption is the human body as a psycho-physical unit. The benefit of spiritual prosumption is then directly experienced as a wellbeing of body and mind. These benefits are gained through a repertoire of techniques, such as yoga postures, which in the context of subjective wellbeing spirituality are often hybrid and flexible. Finally, Dawson calls the modality of spiritual prosumption 'inner-worldly aestheticism', which again refers to the self as both the active agent and the beneficiary of the practise. Viewed thus, the wellbeing practises associated with spirituality appears neither as passive, meaningless consumption nor as an abstract pursuit, detached from economic and cultural realities (Dawson 2013).

The concept of spiritual presumption thus offers a middle way between the criticism directed against the 'consumer takeover of religion' (Carrette \& King 2005; Lau 2000), of which subjective spiritualities are sometimes accused, as well as against claims for purity and authenticity, which ignore the commercial aspects integral to subjective spiritualities. It provides valuable insight into the complex relationship of commercialism and spirituality in the representations of MPY in the Finnish media. Before looking at how these themes are manifested in Finnish magazines, a little attention must be paid to the wider relationship between women, wellbeing and the media.

5 Taira $(2009,239)$ gives the following advice: ' $[\mathrm{I}] \mathrm{t}$ is useful to try to avoid the two extreme alternatives that are reminiscent of the study of fandom - one which sees every kind of politically correct dimension in the discourse on spirituality as progressive or anti-capitalist and the other which deems every kind of reference to spirituality or Eastern wisdom as a surrender to consumer culture or neoliberal ideology.' 


\section{Women, wellbeing, and the media}

As in other wellbeing practises, an overwhelming majority of MPY practitioners are female (Newcombe 2007). According to Sointu and Woodhead (2008), the women taking part in wellbeing activities in Great Britain are predominantly white, well-educated, and involved in humanitarian causes. The consumer segment of 'holistic wellbeing', or 'LOHAS' - Lifestyles of Health and Sustainability (Strauss \& Mandelbaum 2013) - is thus clearly defined. In general, female and feminine are signifiers often defined in relation to consumption in marketing language, whereas the masculine has been customarily associated with the marketer or producer, or established religious institutions (Fisher \& Bristor 1993; Bowlby 2002; Gauthier Martikainen \& Woodhead 2013a).

Sointu and Woodhead (2008) explain the predominance of women in holistic activities by arguing that they simultaneously affirm and challenge the traditional discourses of femininity: nursing is traditionally associated with womanhood, but in holistic activities the attention is shifted from others to oneself. This, in turn, is seen to benefit others as well. Holistic activities thus act to justify focusing on one's own body, health, looks and experiences. Suzanne Newcombe (2008) writes of the British women practicing yoga that they described yoga classes as having improved their ability to perform social duties and responsibilities at home and work (Newcombe 2008, 114.).

Women may also be induced to care for and modify their bodies by cultural standards of beauty and looks. Women's magazines persistently define the ideal body: while there may be articles which emphasize the importance of loving one's body as it is, the pictures typically show an unattainable, ideal body (e.g. Bordo 1993; Markula 2001; Impett et al. 2006; Kyrölä 2014). Conforming to the prevailing ideals, the models featured in the magazines are usually lean and muscular. Additionally, many MPY practitioners associate a healthy, lean and strong body with spiritual progress, viewing it as a sign of bodily and mental discipline (Langøien 2012). On the other hand, yoga and holistic thinking can be argued to offer a healthy balance to the objectification of women, as they advocate taking responsibility of one's own body and wellbeing (Impet et al. 2006).

Middle-class women have been active in health and wellbeing activities such as yoga since the early twentieth century (Newcombe 2007 \& 2008). Although yoga in its pre-20th century Indian contexts was exclusively a male activity, in Europe and the US its audience has from the beginning mainly consisted of women. This had to do with associating yoga with 'exotic dance' and popular forms of female gymnastics: whereas men were supposed to 
train for strength and endurance, yoga was marketed as a way to achieve health and beauty (Singleton 2010; Newcombe 2008). In the light of our research material, we can note that these ideals are still dominant, and that their influence has impacted pervasively on the holistic wellbeing culture.

\section{The study: yoga in the Finnish magazines}

We analyzed the representations of MPY in seven Finnish popular magazines: ET ['Senior's Magazine'], Cosmopolitan [Finnish edition], Hyvä Terveys ['Good Health'], Kodin Kuvalehti ['Illustrated Home Magazine'], Me Naiset ['We Women'], Sara [a woman's name] and Sport [Fitness magazine for women; unrelated to sports magazines in other countries with the same name]. All editorial content including the search words 'yoga' and 'meditation' during the years 2008, 2009, 2010 and the first half of 2011 were collected from each magazine's archives. These seven magazines were chosen to represent a sample of commercial lifestyle magazines which often cover stories concerning subjective wellbeing and exercise. Three of them, Cosmopolitan, Me Naiset and Sara, are profiled as women's magazines focused on fashion and human interest. The others are targeted for a general audience of broad age range, but, according to the publishers' own media information, their readers are mostly females (Sanoma Magazines 2012). Sport magazine is concerned with sports, 'aimed at women who love to keep fit', and Hyvä Terveys is focused on issues of health and wellbeing. ET magazine was chosen to represent a popular publication targeted at the senior population (over50s). Sara, too, is aimed at 'mature' women. Over all, these magazines aim to reach the widest possible audience in the given public market segment. They are therefore significantly dependent on advertisement income, and appeal to an audience favorable to consumerism.

Applying the method of qualitative close reading, the material was read several times, advancing from the phases of data reduction to data display and finally to drawing conclusions and verification (Miles \& Huberman 1994, 10-11; see also Silverman 2000). The analysis was directed by sensitizing (Bulmer 1979) the concepts of spirituality and commercialism. To manage the material, we used the Atlas.ti software, which is designed for the purposes of qualitative analysis.

Firstly, in the data reduction phase, an inductive quantitative approach was utilized. The term 'yoga' was mentioned in altogether 155 articles; yoga was also twice featured on the magazine cover, referring to a story inside. The articles were divided into seven categories according to the 
genre and the role of yoga in the text. On the following readings (data display), we started to delineate and analyze the material thematically with the coding function of Atlas.ti. This made it possible to find similar themes from different parts of the material. After this, we verified the internal coherence of the themes and the way they appeared in different article types. Finally, we selected the articles where spirituality was mentioned in connection with yoga, as well as those about services and yoga-related products.

\section{Overview of the qualitative material}

While the sample of 155 articles in which the term 'yoga' was mentioned is not sufficient for a quantitative research or for drawing statistical generalizations, a quantitative classification was useful in giving an overview of the data and to give direction to the qualitative analysis.

The material was divided into categories $(A-G)$ according to the genre and the role of yoga in the text (table 1). The occurrence of each category in the selected magazines is shown in table 2.

Yoga was most often mentioned in columns (category E): for instance, starting a yoga practise or discussing its effects. Almost half of the columns were found in the magazine Sport, where the journalist Virpi Melleri reported on her experiences of practicing yoga in India. The second largest category (G) consisted of articles where yoga was mentioned in another context, for example as a treatment for insomnia, back pain or loss of weight.

The third largest category of articles were interviews with yoga teachers (Di \& Dii). Yoga was also often referred to in interviews (A), as a part of the lifestyle of the interviewees, who included both public figures and ordinary yoga practitioners. Public figures and celebrities have been instrumental in popularizing yoga not only in Finland, but also in other Western countries. In other instances yoga was mentioned only in passing, for example as a hobby or in the horoscopes (G). Following the common demographic of yoga practitioners, most of the interviewees and models mentioning yoga were white and female.

\section{Close reading spirituality and commercialism}

The overview of the magazine material shows that yoga was mentioned in a wide range of contexts. The word 'spirituality' was explicitly mentioned only in 17 out of 155 articles, but spiritual ideas and symbols are often present in 
the text and imagery. In the majority of the stories, yoga was represented as a form of physical exercise. The articles dealing with yoga-related services, such as yoga classes, retreats and holidays, were classified as commercial in nature. In addition to these, reviews and presentations of accessories, such as clothes, shoes and mats, or books and DVDs, were also classified as commercial (category F). First we explore the theme of spirituality in the research material, then the links between spirituality and commercialism, and finally the rare anomalies featuring critical or hostile reactions to the commercialization of yoga.

\section{Not just exercise}

In the research material, yoga is often categorized as a 'Body \& Mind' exercise, in which the connection between body and mind, proprioception and listening to one's body, are emphasized. Breathing is central to this type of exercise, as it is seen to connect the body and the mind. The emphasis is often on the immediate benefits of the practise: 'Should you choose Ashtanga, Asahi or even Bikram Yoga, what you achieve is a tranquil mind and a healthy body' (Eklöf 2008, 26; all translations are by the authors). Also, yoga is said to enhance the psychological and physical balance, concentration and peace of mind.

This experience of psycho-physical wellbeing is often described in the research material as 'spiritual', and this spiritual aspect of yoga is differentiated from and contrasted to the concept of 'religion'. An article in ET magazine contains an interview with a university lecturer in Comparative Religion, Dr. Måns Broo, who is known for his translations and commentaries of classical yoga texts from Sanskrit to Finnish:

According to Måns Broo, most people look to yoga for health and relaxation, that is, completely secular things.

'If that is what you are after, that is all you are going to get. You cannot accidentally turn Hindu while aiming to get a tighter butt. Yoga is not a religion, although it has a religio-philosophical base. In ancient times, it was mainly a spiritual practice, but nowadays it is thought of first and foremost as physical exercise.

However, if you practice yoga, you will soon notice that the body and the mind are very closely linked. Even if yoga is used merely to treat the body, it will affect the mind as well. All forms of yoga aim at preventing modifications of the mind. Then the mind is at rest, and one can attain a state of pure consciousness. (Ojansivu 2011, 64.) 
In this passage, several interesting points are made. 1) The aim of yoga is defined in an extremely subjective and open-ended way ('If that is what you are after, that is all you are going to get'). 2) Yoga is distinguished from religion, but said to have 'a religio-philosophical base'. 3) The connection between body and mind is emphasized with a reference to 'pure consciousness'. The practitioner is thus presented as a 'sovereign self', who has the freedom to construct a 'hybrid repertoire' best suited to his/her subjective needs. Further, yoga is presented as a way for achieving a qualitative change in consciousness.

Another example emphasizing the difference between religion and spirituality - albeit in an internally contradictory way - is found in the following excerpt from an interview with a yoga teacher:

Yoga is associated with a strong religious aspect. Although mantras are not sung in a Hot Yoga class, Harriet feels that the spiritual side of practise is important. - Yoga is not about practicing a religion, but it is something more than a form of exercise. (Stellan 2008, 44.)

First, yoga is stated to have a 'strong religious aspect'. However, this is immediately countered: 'yoga is not about practicing a religion'. The softening remark, 'but is something more than a form of exercise' is important, as it recurs elsewhere in the material. This can be read as an open-ended reference to the 'spiritual' aspect of the practise, again leaving the 'sovereign self' free to construct a subjective interpretation of its ultimate meaning.

These examples reflect a characteristic rhetoric about spirituality in relation to corporeality in the research material. Plenty of attention is given to the immediate benefits of physical yoga practise, but yoga is often said to be something 'more' than mere physical exercise. This 'spiritual' aspect of yoga is defined in contrast to religion, but otherwise described in an extremely open-ended way. This may have to do with potentially negative connotations associated with religion typical of modern public discourse (Mäenpää 2006; Taira 2006). On the other hand, they can also be seen as typical characteristics of spiritual prosumption, where the agency of the self, the body as the site of prosumption, and hybrid repertoires (including the freedom to construct one's own meanings and methods) form important aspects of the process. 


\section{Commercialism and spirituality}

Although the spiritual aspect of yoga is a recurring theme in the interviews with practitioners and teachers (figure 1: categories $C$ and D), it does not feature prominently as a selling point in the more overtly commercial representations of yoga. These include yoga-related product demonstrations, most commonly yoga mats, books and DVDs (categories B and F), using yoga as a background to illustrate the context of a product, or to mark a lifestyle segment (categories A, C, D, E and G).

For example, the magazine $E T$ invites yoga consumers into 'discussion' with a direct question:

Does your body need gentle stretching, a sweating workout, or both? Nice clothes and good gear give inspiration to your exercise. Yoga wear is soft, warm and flexible. Workout wear needs to be durable, practical and needs to breathe. (Karmila 2008, 73.)

The text gives an impression that soft and flexible clothing is an integral part of the repertoire of yoga, and the clothes are represented as part of the identity of the yoga practitioner, closely linked to the cultural ideals of appearance. As Strauss \& Mandelbaum (2013) have noted, identity plays central part in the current yoga consumerism.

The variety of branded yoga styles is well illustrated in the research material, especially in stories where a reporter is testing a yoga class in a fitness center (category B). For example, Hormonal Yoga is presented as one of the latest ways to package yoga. The term 'hormone' helps not only to brand a specific yoga practice, but also to direct it at women at the age of menopause. For instance, in Sara magazine (Järvinen 2011, 86), 54-yearold Päivi Johansson is interviewed about 'having a sabbatical year and deciding to dedicate it to taking care of herself'. This discourse can be seen as consistent with the 'inner-worldly aestheticism' modality of spiritual prosumption, according which the adopted practises aim at immediate and subjective benefits (Dawson 2013).

An interesting example of using the 'spirituality' associated with yoga as a branding device comes from Me Naiset magazine (Jäntti 2008, 52-53), which encourages the reader to identify her own style of exercise: the reader is asked if she is 'a dancing exerciser', 'a tough plodder' or 'a spiritual mover'. The magazines divide reader segments so that they can find the 'right' product suppliers to advertise in the magazine and fund its contents, since the commercial media function, crucially, by selling audiences to advertisers 
(e.g. Ang 1991). This can also be seen as further evidence of the centrality of identity construction, which in neoliberal societies is characteristically done via consumer choices (Strauss \& Mandelbaum 2013; Gauthier, Woodhead \& Martikainen 2013b).

A list of the sports for the 'spiritual mover' includes various forms of Yoga, Tai Chi, Pilates, Shindo, Asahi stretching, Chi Kung and Feldenkrais. The spiritual mover is described as 'a peace-loving exerciser' who is interested in 'the philosophies behind the sport'. An accompanying illustration features a pair of socks with fitted soles (suggesting the yoga posture Baddhakonasana) under a shining halo, a Christian symbol associated with sainthood. Here it can be understood to connote the 'spiritual qualities' of equanimity, purity, and devotion.

Identity construction aside, the effects on the body and looks dominate the interview excerpt with a 35-year-old female 'spiritual mover'. As if in a yoga advertisement, she testifies to the way her life has changed. Notably, while the story aims at giving tools for constructing 'spiritual identity' among yoga practitioners, no reference to 'spirituality' is made in the interview:

When I started yoga I noticed a new kind of relaxation in my body. My shoulders literally dropped away from my ears. In the yoga poses, my flaccid biceps became firm. The push-ups made firm and slender muscles in my spaghetti arms. The standing poses effectively trim the lower body. Also, some cellulite has done, due to the physical exercise. Woman 35, dynamic yoga. (Jäntti, 2008, 53.)

A story in Sport magazine (Eklöf 2008, 26) utilizes the 'ancient Indian roots' of yoga and spirituality as branding tools: 'yoga, developed thousands of years ago in India, has always taken several different forms. They all have a common goal: spiritual growth and holistic health.' This discourse is repeated in the reviews of yoga books. The Sport Reads column reviews a yoga instruction booklet called Easy Yoga Workbook, by Tara Frazer, persuading the reader that yoga brings instant relief from anxiety and stress:

Get rid of anxiety with yoga.

Rushing and trying to live your life with a tense neck due to stress just does not work in the long run. No way, this has to stop. A shortcut to Nirvana can be achieved with a three-minute relaxation program, which helps enormously. The other exercises in the Easy Yoga Workbook are also accessible to a beginner yogi. (Filpus et al 2008,16.) 
Interestingly, the word 'Nirvana', connoting the metaphysical liberation from suffering in Buddhism, is used here to refer simply to stress reduction. Moreover, the author doesn't seem to be bothered that yoga and Buddhism represent two distinct traditions. A similar conflation of yoga and Buddhism is found in Me Naiset magazine (Jäntti et al 2010, 65): A column on Solar Yoga depicts a winter morning in a yoga studio. The story describes the ambience of the studio and the good after-feeling following the session. The accompanying image shows a woman sitting cross-legged with her fingers in a mudra, a symbolic gesture associated with meditation. (See figure 1.) In the background we can see a statue of the Buddha. Rather than a religious reference, this can be read as using 'spirituality' as a branding device, appealing to the popular associations of relaxation and equanimity with Buddhism.

In another article in Me Naiset (Luhtanen 2010, 40), female practitioners of various sports are recommended specific make-up and skin care products. (See figure 2.) For instance, yoga practitioners are advised to use talc and organic skin creams. This purely commercial text is illustrated with an image of a woman with her palms joined in the atmanjali mudra position, and her head turned toward her heart. This pose expresses a spiritual salutation, and is related to the Hindu belief in the divine nature of each human being (Fuller 1992). Like the image of the halo earlier, this image is being used here to conjure up associations of calmness, purity and devotion.

The most important selling points for yoga thus emerge as looks, wellbeing, a state of relaxation, stress reduction and health. In some rare cases, 'spirituality' is used either as a branding device or a tool for identity construction, mostly through visual motifs associated with religious traditions, which are used as devices to evoke associations with qualities generally perceived as 'spiritual', such as calmness, purity and devotion. Moreover, the imagery and vocabulary associated with spirituality are used to distinguish yoga from other forms of exercise.

\section{A reaction to consumer culture?}

While in the majority of the research material yoga is represented in a commercial context, occasional but clearly recognizable criticism of consumer culture and capitalist society can also be found. For example, a story in Sport magazine (Jalkanen 2009, 18-27) tells the reader about various fitness activities 'which do not require a penny after you have got the gear'. Yoga is represented here as an alternative to commercial sports, especially when 
practiced at home, as it does not require expensive accessories nor classes. The story also presents a few home exercises for the readers.

Critique of consumerism can also be found in rather unexpected places. For instance, Sport magazine (Kokko 2008, 98-101) presents a 'Guide to the sports stores of Helsinki' with celebrity interviews. The introduction encourages the reader: 'Ready, steady, shop!' However, later in the article the well-known Finnish actress Minna Haapkylä comments:

I do my yoga practise at home wearing long johns and a worn out t-shirt. The flea markets are the most important places for me to buy my yoga wear. I do dream about a brand new outfit designed for this activity, but they are so expensive that the long johns will have to do for now. I bought my yoga mat from the Yoga Store on Eerikinkatu. (Kokko 2008, 100.)

Haapkylä's comment clearly stands out as a criticism of consumerism. Although she does admit to 'dreaming about a brand new outfit', and thus returns (or is returned) to the consumerist discourse offered by the journalist, she then reaffirms her disregard for consumerist values by commenting that nice yoga apparel is too expensive and that she is going to stick with her old long johns. Nevertheless, she reveals where she had bought her yoga mat, and the address of the Yoga Store is given at the end of the article to specify a good place to enact one's consumer identity. However, this example raises the question to what extent all modern postural yoga can be approached through the discourse of consumerism. While yoga is certainly presented in the magazine in a commercial manner, Haapkylä's anti-consumerist approach breaks out - or attempts to break out - of this discourse.

Similar sentiments can be found in interviews with other celebrities. In Terveys (Helasti 2008, 18), a well-known Ashtanga Yoga teacher, Juha Javanainen, suggests that the interest in yoga represents a reaction against hard commercial and competitive values. Similarly, a singer and actress, Vuokko Hovatta, says that she loves yoga because - unlike work - you cannot overdo yoga (Hytönen 2010,90). And in a different perspective, a reportage in Sport (Melleri 2010, 30-33) introduces a commercial yoga studio which engages in charity work by allocating ten percent of its profits to funding an orphanage in India.

In these magazines, yoga is often linked with personal growth and changes in lifestyle. Yoga is represented, for instance, as a way to free oneself from addictions and bad habits. Yoga is shown to have given support in rehabilitation after accidents or illnesses, and to be used as relief for 
menopause, insomnia and asthma (e.g. Juusola 2010, 88-94; Järvinen 2011, 86; Rajala 2008, 50-51). Strauss and Mandelbaum (2013) report many similar stories in their media representations research material. Although they are quantitatively rare, these views also constitute an important segment within the totality of the research material.

Finally, therefore, let us examine an example where MPY practise is presented as leading the practitioner into diametrical opposition with consumer culture:

After Leena Weckström had practiced Ashtanga regularly over several months, she began to feel the changes. These occurred in the body and the mind. As she carried on with yoga practise, her values in life started to change as if by themselves. She became vegetarian, and no longer desired meat or fast food. She also almost completely stopped drinking alcohol.

- My life is nowadays mainly work and yoga. I do not need much more than that. I am not hoarding possessions, and I try to help others. Spiritual values are guiding my life, not money. (Ojansivu 2011, 63.)

Anti-consumerist ideas such as these are rare exceptions among the MPY practitioners interviewed, and break away from the mainstream of commercial representations of postural instructions, yoga clothing, and tips for a beauty regimen, represented in a happy marriage with spirituality. However, in the case of MPY, it can be argued that the crucial core commodity is the experience of transformation that follows from following the suggested practises. Dawson (2013) suggests that this transformation is a central feature of the prosumptive process, and indeed, for subjective spiritualities, the central selling point. This perspective also opens up a discussion about the role of yoga as a 'technology of the self' and its inherent ambivalences (Strauss \& Mandelbaum 2013; Askegaard \& Eckhardt 2012; Rindfleish 2006).

\section{Conclusions}

Both scholars of consumption studies (e.g. Wernick 1991; Wightman Fox \& Lears 1983, xiii) and sociologists of religion (e.g. Gauthier, Woodhead \& Martikainen 2013b) argue that consumer culture has invaded all the spheres of social life, including religion, the media, literature, the social sciences, politics and government. Consumption has come to define late-modern selfhood, the modes of social interaction, and the articulation of meanings. Consumerism also forms an integral part of the practise of subjective spirituality, such as MPY. 
However, instead of therefore reducing spirituality to a passive act of consumption, as some critics have suggested (Carrette \& King 2005, Lau 2000), or arguing that consumerism has nothing to do with 'authentic' spirituality, as some practitioners have done, we suggest that the relationship between spirituality and consumerism can be approached with the aid of the conceptual tool of spiritual prosumption (Dawson 2013). In this article we have analyzed the spiritual prosumption, the intertwining of spirituality and commercialism, in representations of yoga in Finnish magazines.

In the magazine representations of MPY, the dominant emphasis, as we would expect, is on the physical practise and its immediate benefits. However, these benefits, such as the experience of the connection between body and mind, are often defined as 'spiritual'. Spirituality is further defined in contrast to 'religion', while its exact meaning is left open. This can be seen to be in accordance with emphasizing the 'sovereign self' as the agent of spiritual prosumption, as well as the utilization of hybrid repertoires, which posit the consuming subject as the final authority on the meaning and form of the practise (Dawson 2013).

Health, wellbeing and beauty are the most common selling points for MPY, but spirituality is sometimes used to differentiate yoga from other forms of exercise, as well as a tool for constructing a particular type of consumer identity. Strauss \& Mandelbaum (2013) have argued that identity plays a central part in the current popularity of yoga. Similarly, visual motifs borrowed from religious traditions may be used to create further associations of yoga with 'spiritual' qualities, such as calmness, equanimity, devotion and purity.

Finally, yoga is presented in the research material as a tool for life change, for example, enhancing health, reducing stress and getting rid of bad habits such as alcohol and smoking. Viewed through Dawson's (2013) definition of spiritual prosumption, this promise of 'transformation' can then be said to be the main 'commodity' associated with commercial representations of yoga. This also links yoga with Foucauldian 'technologies of the self', ways of constructing neoliberal selfhood and of internalizing governance (Strauss \& Mandelbaum 2013; Askegaard \& Eckhardt 2012; Rindfleish 2006).

The stress-reducing and health-promoting effects reported by many yoga practitioners can also be seen from the point of view of optimization of performance. Calling yoga 'a Hindu version of the Protestant ethic', Askegaard and Eckhardt (2012) argue that yoga is not simply a way of relaxation, but also enables its practitioners to take part in capitalist society more efficiently. This also echoes the philosopher Slavoj Žižek's criticism 
of Western Buddhism as the 'perfect ideological supplement' to capitalism, because it provides the practitioner with a sense of relief and detachment while fully participating in the capitalist culture (see Taira 2009). This kind of presentation would also be in line with the commercial nature of the research material.

However, the representations of yoga are not uniformly consumerist. Although extremely rare, the 'transformation' reported by some MPY practitioners in the interview stories is also presented as producing identities and lifestyles that turn away from the values of consumer culture, for example by rejecting a consumer-identity, simplifying one's needs, reducing consumption and engaging in humanitarian causes. Although we acknowledge the rarity of such voices in the material, we find their presence significant, as it conflicts strongly with the overtly commercial nature of the magazines studied.

This leads us to an interesting dilemma: on the one hand, our analysis has shown that in this environment yoga is thoroughly commodified, and works to establish neoliberal selfhood through a process of spiritual prosumption. At the same time, there is some, albeit scarce, evidence that the selfhood produced by yoga might break out of the consumer identities offered by neoliberal discourse. As Askegaard and Eckhardt (2012) also point out, technologies of self may have an ambivalent role in neoliberal societies: on the one hand they embody and promote the central values of neoliberalism such as self-management, flexibility and individual responsibility; at the same time, however, there is some evidence that they can provide tools for using these same values for purposes other than capitalist profit-seeking. Similarly, Strauss and Mandelbaum (2013) have argued that the globalized, commercial nature of yoga has enabled the growth of communities that aim at changing that very same system, for example through ecological activism. While it is impossible to draw any definite conclusions based on this limited material, our study of the representations of yoga in the Finnish print media seems to offer support for this line of argumentation.

LIINA PUUSTINEN, DSocSc, is a Researcher in Media Studies, University of Helsinki, Finland. E-mail: liina.puustinen@helsinki.fi

MATTI RAUTANIEMI, M. Th., is Doctoral Student in Comparative Religion at Åbo Akademi University. E-mail: matti.rautaniemi@abo.fi. 
Bibliography

Alter, Joseph

2004 Yoga in Modern India: the Body Between Science and Philosophy. Princeton, NJ: Princeton University Press.

Ang, Ien

1991 Desperately seeking the audience. London: Routledge.

Askegaard, Søren \& Giana M. Eckhardt

2012 Glocal yoga: Re-appropriation in the Indian consumptionscape. - Marketing Theory 12 (1), 45-60.

Bauman, Zygmunt

2000 Liquid Modernity. Cambridge: Polity.

Bulmer, Martin

1979 Concepts in the Analysis of Qualitative Data. - The Sociological Review 27 (4), 651-77.

\section{Bordo, Susan}

1993 Unbearable Weight: Feminism, Western Culture, and the Body. Berkeley, CA: University of California Press.

\section{Bowlby, Rachel}

2002 Carried Away. The Invention of Modern Shopping. New York, NY: Columbia University Press.

\section{Braedley, Susan \& Meg Luxton}

2010 Neoliberalism and Everyday Life. Canada: McGill-Queen's University Press.

\section{Brown, David \& Leledaki Aspasia}

2010 Eastern Movement Forms as Body-Self Transforming Cultural Practices in the West: Towards a Sociological Perspective. - Cultural Sociology 4 (I), 123-54.

Carrette, Jeremy \& Richard King

2005 Selling Spirituality: The Silent Takeover of Religion. London: Routledge.

Davie, Grace

1994 Religion in Britain Since 1945: Believing Without Belonging. Oxford: Blackwell.

\section{Dawson, Andrew}

2013 Entangled Modernity and Commodified Religion: Alternative Spirituality and the 'New Middle Class'. - Gauthier and Martikainen (eds.) Religion in Consumer Society: Brands, Consumers and Markets, 127-42. Farnham, Surrey: Ashgate. 


\section{De Michelis, Elizabeth}

2004 A History of Modern Yoga: Patañjali and Western Esotericism. London \& NewYork: Continuum.

\section{Fisher, Eileen \& Julia Bristor}

1994 A feminist poststructuralist analysis of the rhetoric of marketing relationships. - International Journal of Research in Marketing 11 (4), 317-31.

Fish, Alison

2006 The Commodification and Exchange of Knowledge in the Case of Transnational Commercial Yoga. - International Journal of Cultural Property 13 (02): 189-206.

Fuller, C. J.

1992 The Camphor Flame: Popular Hinduism and Society in India. Princeton, NJ: Princeton University Press.

\section{Gallup Ecclesiastica}

2011 Kirkon tutkimuskeskus (Church Research Institute, the Evangelical Lutheran Church of Finland). The electronic archives of the Kirkon tutkimuskeskus. Survey data collection TNS Gallup.

Gauthier, François \& Tuomas Martikainen \& Linda Woodhead

2013a Introduction: Religion in Market Society. In: Martikainen and Gauthier (ed.) Religion in the Neoliberal Age: Political Economy and Modes of Governance, 1-18. Farnham, Surrey: Ashgate.

Gauthier, François \& Linda Woodhead \& Tuomas Martikainen

2013b Introduction: Consumerism as the Ethos of Consumer Society. In: Gauthier and Martikainen (ed.) Religion in Consumer Society: Brands, Consumers and Markets, 1-24. Farnham, Surrey: Ashgate.

Harvey, David

2007 A Brief History of Neoliberalism. Oxford: Oxford University Press.

\section{Hasselle-Newcombe, Suzanne}

2005 Spirituality and 'Mystical Religion' in Contemporary Society: A Case Study of British Practitioners of the Iyengar Method of Yoga.- Journal of Contemporary Religion 20(3): 305-21.

Heelas, Paul

2008 The Spiritualities of Life: New Age Romanticism and Consumptive Capitalism. Malden, MA: Blackwell.

Heelas, Paul \& Linda Woodhead \& Benjamin Seel \& Bronislaw Szerszynski \& Karin Tusting

2005 The Spiritual Revolution: Why Religion Is Giving Way to Spirituality. Malden, MA: Blackwell. 


\section{Impett, E \& J. Daubenmier \& A. Hirschman}

2006 Minding the Body: Yoga, Embodiment, and Wellbeing. - Sexuality Research E Social Policy 3(4): 39-48.

\section{Jain, Andrea R.}

2012 Branding Yoga: The Cases of Iyengar Yoga, Siddha Yoga and Anusara Yoga. - Approaching Religion 2(2): 3-17.

2014 Who Is to Say Modern Yoga Practitioners Have It All Wrong? On Hindu Origins and Yogaphobia. - Journal of the American Academy of Religion 82 (2): 427-71

\section{Kyrölä Katariina}

2014 The Weight of Images: Affect, Body, Image and Fat. Farnham, Surrey: Ashgate.

\section{Langøien, Lars Jørun}

2012 Yoga, Change and Embodied Enlightenment. - Approaching Religion $2(2), 27-37$.

Lau, Kimberly J.

2000 New Age Capitalism: Making Money East of Eden. Philadelphia, PA: University of Pennsylvania Press.

\section{Lears, Jackson TJ}

1983 From Salvation to Self-Realization: Advertising and the Therapeutic Roots of the Consumer Culture, 1880-1930. - Wightman Fox R and Lears J T J (ed), The Culture of Consumption: Critical Essays in American History, 1880-1980, 1-38. New York, NY: Pantheon Books.

\section{Markula, Pirkko}

2001 Beyond the Perfect Body: Women's Body Image Distortion in Fitness Magazine Discourse. - Journal of Sport E Social Issues, 25 (2), 158-79.

\section{Miles, Matthew B. \& Michael A. Huberman}

1994 Qualitative Data Analysis. Thousand Oaks, CA: Sage.

\section{Mäenpää, Pasi}

2006 Urbaani elämäntapa ja sen uusi uskonnollisuus. In: Mikkola, Teija; Niemelä, Kati; Petterson, Juha (eds.): Urbaani usko. Nuoret aikuiset, usko ja kirkko. Kirkon tutkimuskeskuksen julkaisuja 96, 317-30. Tampere: Kirkon tutkimuskeskus.

\section{Nevrin, Klaes}

2008 Empowerment and Using the Body in Modern Postural Yoga. Singleton and Byrne (eds.) Yoga in the Modern World: Contemporary Perspectives, 119-139. London, New York: Routledge, 119-39.

\section{Newcombe, Suzanne}

2007 Stretching for Health and Wellbeing: Yoga and Women in Britain, 1960-1980. - Asian medicine 3 (1), 37-63. 
2008 A Social History of Yoga and Ayurveda in Britain, 1950-1995. Ph.D. Dissertation, Faculty of History, University of Cambridge.

Philp, John

2009 Yoga, Inc. A Journey Through the Big Business of Yoga. Toronto: Penguin Group.

\section{Possamai, Adam}

2003 Alternative Spiritualities and the Cultural Logic of Late Capitalism. - Culture and Religion: An Interdisciplinary Journal, 4 (1), 31-45.

Read, Jason

2009 A Genealogy of Homo-Economicus: Neoliberalism and the Production of Subjectivity. - Foucault Studies, 6, 25-36.

\section{Rindfleish, Jennifer}

2006 Consuming the Self: New Age Spirituality as 'Social Product' in Consumer Society. - Consumption, Markets and Culture 8 (4), 343-60.

\section{Ritzer, George \& Paul Dean \& Nathan Jurgenson}

2012 The Coming of Age of the Prosumer. American Behavioral Scientist 56 (4), 379-98.

\section{Ritzer, George \& Nathan Jurgenson}

2010 Production, Consumption, Prosumption: The Nature of Capitalism in the Age of the Digital 'Prosumer'. Journal of Consumer Culture, 10 (1), 13-36.

\section{Sanoma Magazines}

2012 Media Guide. <http://www. sanomamagazines.fi>, accessed 18 December 2012.

\section{Singleton, Mark}

2010 Yoga Body: The Origins of Modern Posture Practice. Oxford: Oxford University Press.

\section{Silverman, David}

2000 Doing Qualitative Research: A Practical Handbook. London: Sage.

\section{Sointu, Eeva \& Linda Woodhead}

2008 Spirituality, Gender, and Expressive Selfhood. - Journal for the Scientific Study of Religion, 47 (2), 259-76.

\section{Speck, Simon}

2013 Religion, Individualisation and Consumerism: Constructions of Religiosity in 'Liquid' and 'Reflexive' Modernity. - Gauthier and Martikainen (ed.) Religion in Consumer Society: Brands, Consumers and Markets, 27-42. Farnham, Surrey: Ashgate. 


\section{Springer, Simon}

2012 Neoliberalism as discourse: between Foucauldian political economy and Marxian poststructuralism. - Critical Discourse Studies 9 (2), $133-47$.

\section{Strauss, Sarah}

2005 Positioning Yoga. Balancing Acts Across Cultures. Oxford \& New York: Berg.

\section{Strauss, Sarah \& Laura Mandelbaum}

2013 Consuming Yoga, Conserving the Environment: Transcultural Discourses on Sustainable Living. - B. Hauser (ed.), Yoga Traveling. Transcultural Research: Heidelberg Studies on Asia and Europe in Global Context. Basel: Springer.

\section{Suomen kuntoliikuntaliitto}

2010 Kansallinen liikuntatutkimus 2009-2010: Aikuisliikunta. SLU:n julkaisusarja 6/2010. Available at: http://www.kunto.fi/@Bin/278890/Liikuntatutkimus_aikuisliikunta_2009-2010.pdf (accessed 15 March 2013).

\section{Taira, Teemu}

2006 Notkea uskonto. Turku: Eetos.

2009 The Problem of Capitalism in the Scholarship on Contemporary Spirituality - Tore Ahlbäck (ed.), Postmodern Spirituality, 230-44. Turku: Donner Institute.

\section{Wernick, Andrew}

1991 Promotional culture: Advertising, ideology and symbolic expression. London, Sage.

\section{Wightman Fox, Richard \& T. J. Jackson Lears (eds.)}

1983 The Culture of Consumption: Critical Essays in American History, 18801980. New York, NY: Pantheon Books.

\section{Zwick, Detlev \& Samuel K. Bonsu \& Aron Darmondy}

2008 Putting Consumers to Work. 'Co-creation' and new marketing governmentality. Journal of Consumer Culture 8 (2), 163-96.

Magazines

Eklöf, Maria

2008 'Jooga vai Pilates. Löydä omasi pehmeistä lajeista', Sport 3, 26.

Filpus, Leena \& Anna Jalkanen \& Ulla-Maija Paavilainen \& Liisa Rajala \& Heini Virta

2008 'Sport lukee: Joogaa ahdistus pois,' Sport 3, 16. 


\section{Helasti, Pirjo}

2008 'Harrasta mielenrauhaa', Terveys 2, 18-19.

\section{Hytönen, Johanna}

2010 'Hitaasti hyvää', Terveys 8, 90.

\section{Jalkanen, Anna}

2009 'Miss Money. Köyhä voi tehdä paljon muutakin kuin kyykätä' Sport $1,18-27$.

\section{Juusola, Mervi}

2010 'Menopaussin viisaus ja nautinto', Sara 4, 88-94.

\section{Jäntti, Elina}

2008 'Liikkumalla lihaksia', Me Naiset, August 28 2008, 52-3.

Jäntti, Elina \& Marjut Laukia \& Johanna Lätti \& Heini Maksimainen

2010 'Hyvä fiilis 2010, Aurinko tuli joogasaliin', Me Naiset, October 21 2010, 65.

\section{Järvinen, Virve}

2011 'Hiki hoitaa', Sara 3, 86.

Karmila, Anna

2008 'Joogaten \& jumpaten', ET 13, 73.

\section{Kokko, Liisa}

2008 'Opas Helsingin urheilukauppoihin. Paikoillanne, valmiit, shoppaamaan', Sport 9, 98-101.

\section{Luhtanen, Iia}

2010 'Raikkaana radalle'. Me Naiset, July 29 2010, 40.

\section{Melleri, Virpi}

2010 'Hyvä kiertämään', Sport 11-12, 30-3.

\section{Ojansivu, Merja}

2011 'Luja ja lempeä jooga'. ET, 11, 61-4.

\section{Rajala, Liisa}

2008 'Keuhkot pihalle', Sport 1, 50-1

\section{Stellan, Sanna}

2008 'Työ käy kuin leikki', Me Naiset, April 30 2008, 44. 


\section{Appendix.}

Table 1. Classification of the articles mentioning 'yoga'.

A) personal interview

B) presentation of a certain type of exercise

Bi) yoga is presented as an aspect of the whole

Bii) yoga is the main focus

C) interview of a practitioner

D) interview of a yoga teacher

Di) as a part of a larger context

Dii) as a separate article

E) column

F) product review (e.g. accessories, mats, books and DVDs)

G) yoga as part of a wider context.

Table 2. Occurrence of the categories in each magazine.

\begin{tabular}{|l|c|c|c|c|c|c|c|c|c|c|}
\hline Magazine & $\begin{array}{l}\text { Story } \\
\text { category }\end{array}$ & & & & & & & & & Total \\
\hline & $\mathrm{A}$ & $\mathrm{Bi}$ & $\mathrm{Bii}$ & $\mathrm{C}$ & $\mathrm{Di}$ & $\mathrm{Dii}$ & $\mathrm{E}$ & $\mathrm{F}$ & $\mathrm{G}$ & \\
\hline Hyvä Terveys & 2 & & 2 & 5 & 4 & & & 1 & 5 & 19 \\
\hline MeNaiset & 5 & 3 & & & 5 & 1 & 8 & 1 & 7 & 30 \\
\hline KodinKuvalehti & & & & 3 & & & 2 & & 4 & 9 \\
\hline Sara & 3 & 1 & & 5 & & & 2 & & 4 & 15 \\
\hline Cosmopolitan & & 1 & 1 & 1 & 1 & 1 & 9 & 1 & 7 & 22 \\
\hline ET & 1 & & & 1 & & 1 & 8 & 1 & 1 & 13 \\
\hline Sport & 5 & 1 & 2 & & 5 & 2 & 20 & 6 & 10 & 47 \\
\hline $\begin{array}{l}\text { Total } \\
\text { all magazines }\end{array}$ & 16 & 6 & 5 & 15 & 15 & 5 & 49 & 10 & 40 & 155 \\
\hline
\end{tabular}


Figure 1. 'The sun came to the yoga shala.' Me Naiset magazine's 'Good Feeling' column on Solar Yoga (Jäntti et al 2010, 65).

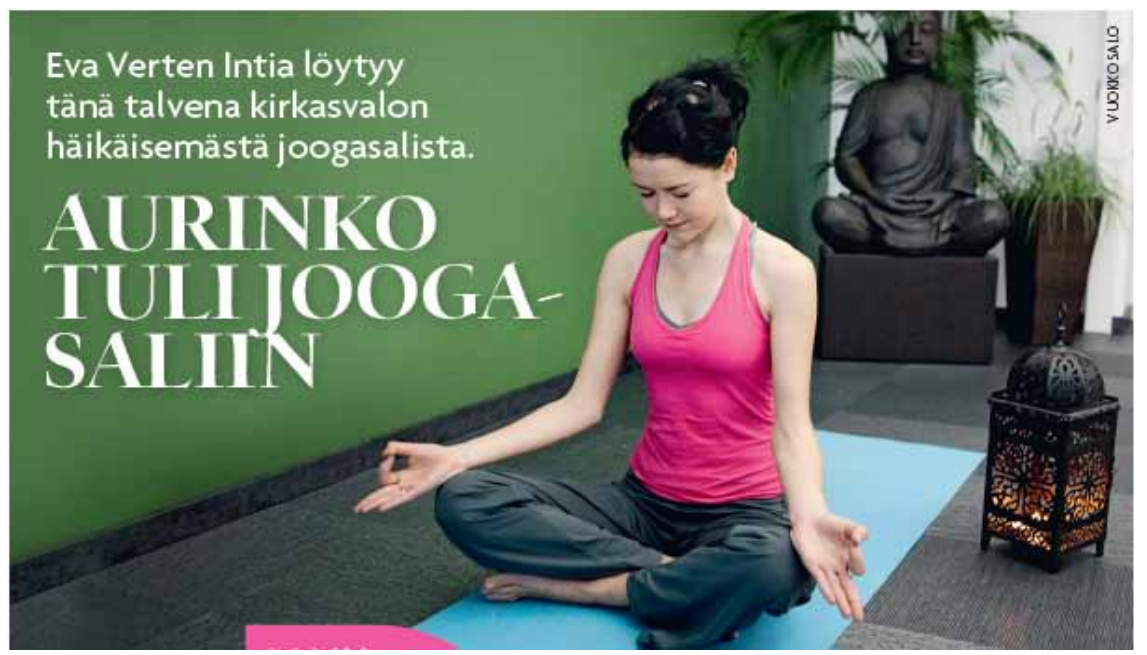


Figure 2. 'Fresh to the track. When you choose beauty products the match your activity, sports are much more fun.' Article on sport activities and cosmetics in Me Naiset magazine (Luhtanen 2010, 40).

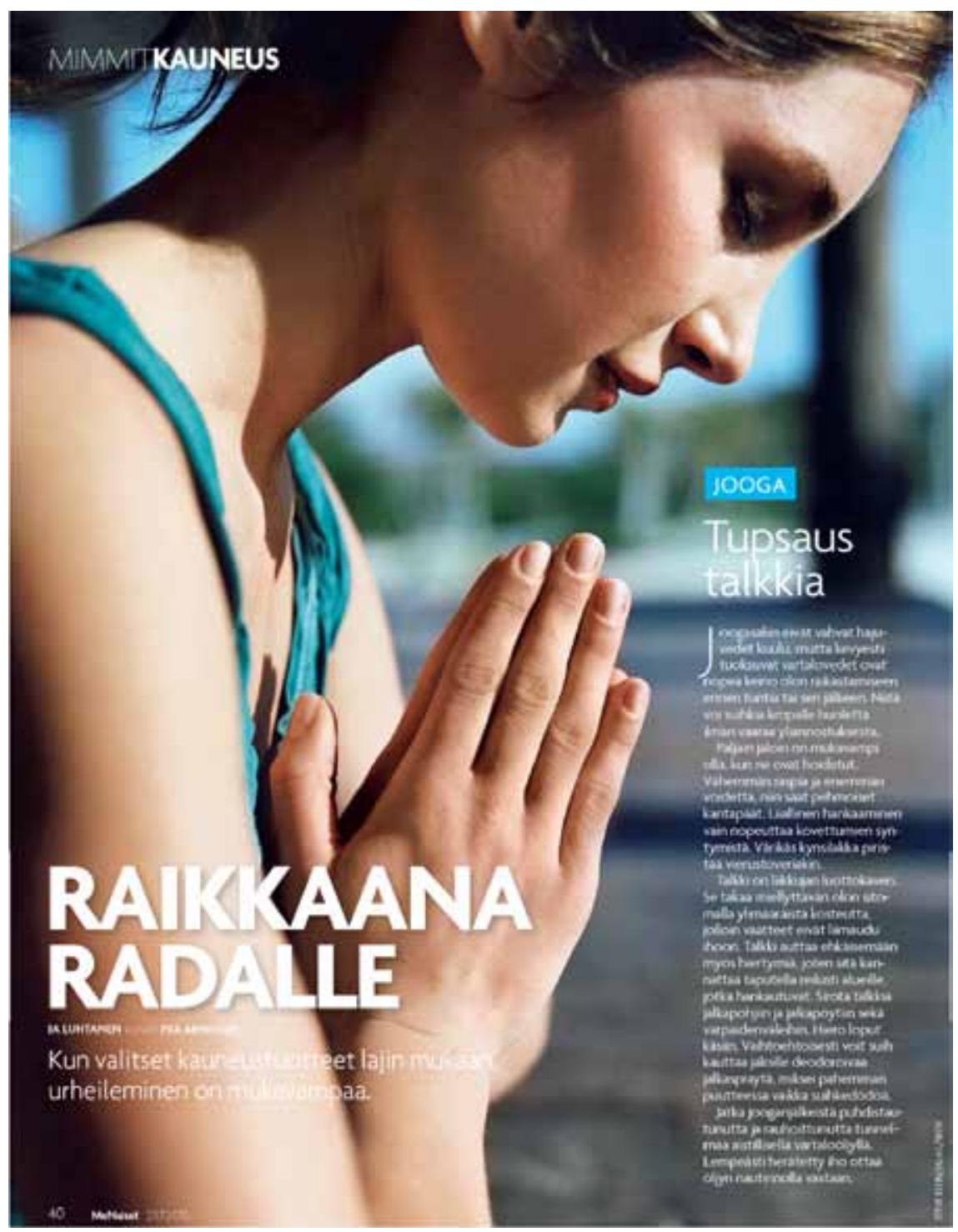

